Archaeologia Historica Polona tom 26, 2018, ISSN 1425-3534

Instytut Archeologii

http://dx.doi.org/10.12775/AHP.2018.003

Uniwersytet Mikołaja Kopernika

w Toruniu

DARIUSZ POLIŃSKI

\title{
Gród czy zamek? Desygnaty terminów oraz konsekwencje ich stosowania w archeologii historycznej i ochronie zabytków
}

\section{Stronghold or castle? The referents of terms and the consequences of their application in historical archaeology and heritage protection}

Zarys treści: Próba określenia desygnatów terminów „gród” i „zamek” w oparciu o dotychczasową literaturę przedmiotu i informacje w źródłach pisanych. Zwrócenie uwagi na różnice i podobieństwa założeń obronnych określanych tymi nazwami. Jako przykłady przywołano obiekty warowne, między innymi z obszaru władztwa zakonu krzyżackiego, w tym takie, które pozwalają w inny sposób spojrzeć na pozornie oczywiste kwestie. Konsekwencje stosowania opisywanej nomenklatury w archeologii historycznej i ochronie zabytków.

Słowa kluczowe: średniowiecze, nowożytność, gród, zamek, dwór, nazwy założeń obronnych w przekazach pisanych (castrum, curia, hus, Schloss, fortalicium i inne), archeologia historyczna, ochrona zabytków.

Zakres problematyki badawczej dotyczącej zarówno grodów, jak i zamków jest bardzo złożony i obszerny, o czym zaświadczy ogrom literatury na ten temat. W trakcie wspomnianych badań podejmowano też próby zdefiniowania terminów „gród” i „zamek”, również w kontekście transformacji założeń obronnych. Głos w tej sprawie zabierali zarówno archeolodzy ${ }^{1}$, jak też historycy sztuki i architektury. Jednak wypracowane dotąd poglądy i stanowiska, dodajmy, że dość zróżnicowane, pozostawiają nadal wątpliwości ${ }^{2}$. Problem ten dotyczy w szczególności archeologów badających założenia obronne z czasów historycznych,

\footnotetext{
${ }^{1}$ Por. np. Kołodziejski 1994, s. 11 (tam starsza literatura); z nowszych prac - por. Poliński 2005.

${ }^{2}$ Na temat form osadnictwa, związanych ze stanowiskami określanymi jako grodziska i kłopotami w interpretacji - por. Marciniak-Kajzer 2013.
} 
zmuszonych uwzględniać ex definione wyniki studiów historyków. Stąd też warto po raz kolejny zastanowić się nad niektórymi kwestiami związanymi z tym zagadnieniem, w szczególności konsekwencjami stosowania wymienionych wyżej terminów w archeologii historycznej i ochronie zabytków.

Należy podkreślić, że niniejsze rozważania nie będą rościły sobie prawa do całościowego i szczegółowego ujęcia tematu, będąc raczej głosem w dyskusji w oparciu o różne przykłady obiektów, między innymi z obszaru władztwa zakonu krzyżackiego, szczególnie zaś takich, które pozwalają w inny sposób spojrzeć na pozornie oczywiste kwestie.

Prezentacja interesującej nad tematyki nie jest możliwa bez zdefiniowania podstawowych terminów oraz określenia ich desygnatów. Niezbędne jest też uwzględnienie nomenklatury ze źródeł pisanych, głównie średniowiecznych i nowożytnych, oczywiście w związku z ówczesnymi uwarunkowaniami społeczno-gospodarczymi i politycznymi. Dysponując taką wiedzą możliwa jest weryfikacja niektórych teorii i hipotez dotyczących rozwoju architektury obronnej, w ramach której zasadniczo są postrzegane takie formy osadnictwa jak grody i zamki.

Na wstępie warto przytoczyć pytanie postawione przez Leszka Kajzera dotyczące dolnej cezury występowania zamków: „Czy [...] każdy obiekt zawierający w sobie element zamknięcia można nazwać zamkiem?”, który zarazem wyraził wątpliwość, że: ,[...] stosując konsekwentnie ten wyróżnik zamkami trzeba by nazywać prawie wszystkie budowle (kompleksy budynków) otoczone murami, wałami, fosami, parkanami itp.” (Kajzer 1980, s. 20).

Równie ważne, można powiedzieć, że kluczowe w stosunku do obiektów późnośredniowiecznych i nowożytnych, jest również pytanie o górną cezurę występowania grodów, oczywiście w odniesieniu do założeń obronnych bądź obronno-rezydencjonalnych. Inaczej mówiąc, czy w interesujących nas przedziałach czasowych możemy mówić nie tylko o zamkach i dworach, ale czy jest jeszcze miejsce na grody? W literaturze przedmiotu pojawia się bowiem, w odniesieniu do obiektów funkcjonujących po potopie szwedzkim (2. połowa XVII-XVIII wiek), określenie tzw. grodziska sarmackie i folwarczne (Kajzer 1993, s. 41). Część fortalicji stanowiła adaptację form wczesnośredniowiecznych, przy czym nie chodzi tu tylko o wykorzystanie reliktów grodów, ale o zastosowanie dawnych technik budowy, czy rozplanowania obiektów (por. np. fortalicja rycerska w Ryńsku; Kola 1991, s. 78-79, 88). Obecnie większość badaczy nie ma wątpliwości, że obyczaj lokowania dworów na kopcach, nawiązujących do idei wczesnośredniowiecznych założeń typu motte, ostatecznie zanikł dopiero u schyłku Rzeczypospolitej Szlacheckiej, a dokładniej na przełomie XVIII i XIX wieku (Kajzer 2004, s. 158) ${ }^{3}$.

${ }^{3}$ Dobrym przykładem może tu być na przykład Wrząca, stanowiąca centrum późnośredniowiecznej włości Świnków, a potem do II wojny światowej Grodzickich, w której obecność fortalicji stanowiącej własność przedstawiciela tego rodu - Piotra Zajączka odnotowano w 1488 roku. Pozostała po niej wyspa na dworskim stawie, kryjąca w sobie nawarstwienia kulturowe, pozostałe po kolejnych dworach drewnianych - średniowiecznych i nowożytnych (te ostatnie notowane w źródłach 
„Gród” z etymologicznego punktu widzenia to miejsce ogrodzone, obronne, niezależnie, czy umocnienia składały się z prostego ostrokołu, czy też potężnego wału drewniano-kamienno-ziemnego (Leciejewicz 1978, s. 51). Z kolei w „Słowniku terminologicznym architektury” zdefiniowano „gród”, jako zespół osadniczy przystosowany do obrony, $\mathrm{z}$ reguły w systemie ścianowym lub zatokowym, przy maksymalnym wykorzystaniu warunków obrony terenu i zastosowaniu umocnień w postaci konstrukcji drewnianych (np. częstokół), ziemno-drewnianych (np. obwałowania), ziemnych (fosa), a wyjątkowo murowanych (mury lub płaszcz kamienny chroniący wały). Dalej czytamy, że znaczniejsze grody z reguły miały jedno lub kilka związanych z nimi i również obwarowanych podgrodzi. W średniowieczu stanowiły one warowną siedzibę księcia lub kasztelana (castrum) (Bogdanowski, Holcer, Kornecki 1994, s. 17). Dalsza część podanej definicji wskazuje na duże zróżnicowanie grodów ${ }^{4}$. Tę cechę grodów podkreślają także inni badacze, zawsze jednak dwie ich podstawowe funkcje wysuwały się na pierwszy plan: ustrojowa - jako ośrodków życia publicznego ${ }^{5}$ i militarna - jako miejsca schronienia i obrony (Leciejewicz 1978, s. 51). Zdefiniowano także pojęcie "gródek", uznając go po prostu za mały gród lub niewielką fortyfikację polową z czasów nowożytnych (Bogdanowski, Holcer, Kornecki 1994, s. 17).

Z kolei „zamek” może być rozumiany jako obiekt będący samodzielnym zespołem elementów obronnych, takich jak wały, mury, baszty itp. oraz zabudowań mieszkalnych, powiązanych w zamknięty obwód warowny i łączący funkcję obronną z zadaniami mieszkalnymi i gospodarczymi. W tej definicji, obok kryterium funkcjonalnego, bardzo podkreślany jest związek zamku z formacją feudalną - jako rezydencja panującego i feudała - a nie z budulcem czy obrazem formalnym (Pietrzak 2003, s. 19; por. też Guerquin 1984, s. 15; Słownik terminologiczny 1976, s. 499; Kajzer, Kołodziejski, Salm 2003, s. 9).

w latach 1711-1792), a Grodziccy przenieśli się z drewnianego dworu na kopcu do nowego dworu murowanego dopiero w 1800 roku (Kajzer 2004, s. 158-159).

${ }^{4}$ Według autorów „Słownika” rodzaje grodów rozróżnia się w zależności od: 1) funkcji - rezydencjonalne, administracyjne, strażnicze, refugialne, pramiasta, 2) usytuowania - wyżynne i nizinne, 3) morfologii - pierścieniowe, podkowiaste, wieloboczne, stożkowate, z wałem poprzecznym, 4) ukształtowania przestrzennego - jedno-, dwu- lub wieloczłonowe (w związku z pełnioną funkcją bądź w wyniku rozwoju przestrzennego), 5) elementów obronnych - palisadowe (otoczone częstokołem) i ziemnowałowe (Bogdanowski, Holcer, Kornecki 1994, s. 17).

${ }^{5}$ W państwie pierwszych Piastów grody były podstawą tzw. systemu grodowo-kasztelańskiego, czyli organizacji stanowiącej zasadniczą strukturę umożliwiającą zarządzanie monarchią (Kajzer 2010, s. 27-28, 30).

6 Termin „zamek” (semantyczna kalka niemieckiego słowa Schloss) pojawia się po raz pierwszy w gramatyce Jana z Tucholi (1533 rok) jako synonim castrum i arx, modnego wówczas określenia najbardziej warownej części miasta: arx munitior pars urbis. Kolejne wydania podręcznika prawa miejskiego tego autora unaoczniają wahania terminologiczne: „,castrum - zamek, gród (1540 rok), twierdza, pałac królewski, dwór (1607 rok)", ale: castrum in singulari est domus muro aut vallo aut fossis vallata. Wyraz ,zamek” był więc rodzimą kontynuacją wieloznacznego łacińskiego castrum i jako taki został utrwalony w literaturze przez Marcina Bielskiego (Kronika polska 1551, 1554, 1564 i nn.). 
W trakcie wieloletniej dyskusji na temat czym są zamki i grody oraz ich wzajemnych relacji i chronologii, pojawiły się różne stanowiska i poglądy, niekiedy dość skrajne, czy charakterystyczne dla określonych środowisk i dyscyplin naukowych. Konieczność ograniczenia zakresu definicji ,zamku” i zarezerwowania go jedynie dla budowli murowanych już wcześniej dostrzegali zwłaszcza historycy sztuki i architektury, ale kryterium konstrukcyjne stosują też archeolodzy i historycy sensu stricto (Pietrzak 2003, s. 19)7. Rozróżnienie takie, o czym niżej, nie znajduje jednak zazwyczaj uzasadnienia w przekazach pisanych, zarówno średniowiecznych, jak też nowożytnych.

Radykalne stanowisko w tej kwestii zajął Jerzy Rozpędowski, który obserwując rozwój budownictwa obronnego w Polsce (do XIII wieku) i definiujące określenia ,grodu” jako jednostki militarnej, ,palatium” rozumianego nie jako pałac-dom, ale jako założenie przestrzenne, jak też ,zamku”, nie widzi między tymi obiektami istotnych różnic, które pozwalałyby na ich oddzielne rozpatrywanie. Uważa on, że w każdym przypadku, niezależnie od użytego materiału budowlanego, jest to obwarowana siedziba mieszkalna pana powstała w ustroju feudalnym ${ }^{8}$. Ta jedność - zdaniem cytowanego badacza - odzwierciedla się i w słowiańskim nazewnictwie, gdzie poza Polską nazwy „gród”, „grad”, „gard”, „hrad" stosuje się dla wszystkich obiektów obronnych. Podobnie też w państwach Europy Zachodniej określano warownie średniowieczne jednym mianem château lub Burg, bez względu na materiał i formę (Rozpędowski 1978, s. 92, 94). Dolną cezurę pojawienia się zamków na ziemiach polskich J. Rozpędowski określa już na VIII wiek ${ }^{9}$, rezerwując termin ,gród" dla obiektów warownych z formacji przedfeudalnych (Rozpędowski 1978, s. 94-95), a więc głównie pradziejowych ${ }^{10}$. Podkreślił też, że mimo zmian zachodzących w zamkach wskutek doskonalenia się sztuki wojennej i techniki oblężniczej, nie należy wprowadzać różnicujących nazw, gdyż niepotrzebnie mogą one sugerować inne treści, nawet wbrew intencji piszących autorów (Rozpędowski 1978, s. 95). Z pewnością jednak należy zgodzić się z twierdzeniem autora, że połowa XIII wieku jest sztuczną granicą podziału w dziejach architektury militarnej (Rozpędowski 1978, s. 91), tak więc nie należy

Tak jak castrum, nadal służył do określania przestrzeni zorganizowanej do potrzeb obrony i reprezentacji. Oznaczał nie tylko rezydencję władcy i siedzibę feudalną, ale też obwód, obwód warowny i osadę warowną (Dobrzański 1978, s. 5).

${ }^{7}$ Należy też brać pod uwagę rozróżnienie założeń zbudowanych przez władców terytorialnych, zwykle skalą odbiegających od fundacji rycerskich, mieszczańskich i sołtysich (por. ostatnio Nowakowski 2017, s. 13).

${ }^{8}$ Według Jerzego Rozpędowskiego materiał stosowany w warowniach również nie jest ich wyróżnikiem typologicznym, bowiem każdy z trzech zdefinowanych przez niego typów zamków może być murowany, mieć strukturę drewniano-ziemną lub mieszaną (Rozpędowski 1978, s. 94).

${ }^{9}$ W odniesieniu do obiektów z ziem Polski o małych powierzchniach, datowanych od VII-VIII do X wieku, Jerzy Rozpędowski użył określenia „protozamki” (Rozpędowski 1978, s. 92).

${ }^{10}$ Najbardziej oczywistym przykładem w tym kontekście wydaje się wskazanie halsztackiej osady obronnej w Biskupinie. 
ograniczać funkcjonowania budownictwa grodowego do około połowy XIII wieku, a zamkowego od połowy XIII wieku.

Większość badaczy nie kwestionuje jednakże istnienia na ziemiach Polski we wczesnym średniowieczu (do XII-XIII wieku) form osadnictwa obronnego, które należałoby określić nazwą ,gród”, mimo wieloznaczności tego terminu. Terytorium państwa wczesnopiastowskiego zostało podzielone na okręgi grodowe, występujące w źródłach jako castrum $^{11}$. W ich centrach znajdowały się grody drewniano-ziemne - założenia obronno-mieszkalne, składające się z wałów (i innych urządzeń obronnych), chroniących ulokowane na dziedzińcu zabudowania i domostwa. Były to także, przynajmniej nominalnie, siedziby kasztelanów (Kajzer 2010, s. 28).

$\mathrm{Z}$ pewnością już te przytoczone wyżej cechy grodu i zamku wskazują na wyraźne elementy wspólne, z czego najczytelniejsze jest ,zamknięcie”. Możliwości z jednej strony traktowania jako zamki między innymi średniowiecznych drewniano-ziemnych obiektów obronnych, nazywanych grodami, czy gródkami, niezależnie od ich skali założenia i funkcji, z drugiej strony występowanie obiektów łączących w sobie cechy zarówno „klasycznych” zamków, jak i grodów, doprowadziła do powstania koncepcji tzw. zamków typu przejściowego (hrady přechodného typu; Durdík 1978). Hrad přechodného typu był w ramach typologii obiektów warownych z terenu Czech ogniwem łączącym założenia obronne z wczesnego i późnego średniowiecza (Nowakowski 2017, s. 13). Określenie to na polski grunt przeniósł Artur Boguszewicz, używając go dla pewnego typu warowni książęcych, najczęściej wieloczłonowych, otoczonych rozbudowanym systemem obronnym, z zabudową wewnętrzną wzniesioną bez użycia zaprawy murarskiej. Obiekty takie występowały przede wszystkim w strefie Przedgórza Sudeckiego (Boguszewicz 1998, s. 103-104, przypis 46). Chociaż Dominik Nowakowski w swojej najnowszej pracy uważa, że z perspektywy czasu wprowadzenie do obiegu naukowego terminu ,zamek typu przejściowego" należy ocenić jako niezbyt trafne (Nowakowski 2017, s. 12-13), to jednak sprawa wymaga dalszych studiów, nie tylko w oparciu o obiekty z Czech i Śląska, ale także z terenu władztwa zakonu krzyżackiego (Poliński 2005, s. 184-186, 192; 2016; Gazda 2013) ${ }^{12}$.

${ }^{11}$ Złożoność problematyki badawczej związanej z terminem castrum starał się zaprezentować Saba J. Dobrzański (1978), zastrzegając przy tym, że celem jego pracy nie jest ustalenie definicji tego terminu. Na podstawie różnorodnych źródeł pisanych, pochodzących z Europy i Bliskiego Wschodu, począwszy od antyku aż po renesans, autor dowodzi, że nazwa castrum wymaga szczególnie adekwatnego posługiwania się terminologią - wszystkie określenia należy rozpatrywać w zależności od środowiska i czasu w jakich powstały (Dobrzański 1978, s. 5).

12 Warto w tym miejscu zwrócić uwagę, że z praktyką adaptacji starszych obiektów warownych, czy nawet ich reliktów (m.in. wczesnośredniowiecznych grodzisk), pod budowę na przykład fortalicji na kopcach (typu motte), spotykamy się dość często w różnych częściach Europy. Wykorzystywano niejednokrotnie relikty rzymskich kaszteli i celtyckich oppidów, czy adaptowano niewielkie, wczesnośredniowieczne gródki pierścieniowate (tzw. terp i ringwork) (Nowakowski 2017, s. 94). Na niektórych obszarach jeszcze długo budowano obiekty określane jako ringwork, obok założeń typu motte (m.in. Marschall 2007, s. 21-22), co oznacza przeżywanie się tradycji wczesnośredniowiecznej także w odniesieniu do architektury obronnej. 
Terminem, który również wypada wymienić w kontekście rozważań o zamkach i grodach jest „dwór”, zwłaszcza w odniesieniu do obiektów późnośredniowiecznych ${ }^{13}$ i nowożytnych. Zdaniem Janusza Pietrzaka „dwór obronny” to budynek mieszkalny wraz z podwórzem i zabudowaniami gospodarczymi, czyli zespół domu feudała z niezbędnym zapleczem zapewniającym jego właściwe funkcjonowanie oraz charakteryzujący się „półobronnością” ${ }^{14}$, rozumianą jako możliwość biernego przetrwania ataku bądź podejmowania obrony czynnej dzięki położonym w zespole budowlom obronnym (Pietrzak 2003, s. 22) ${ }^{15}$. W takim ujęciu „dwór obronny”, czy raczej dwór o cechach obronnych, można by pomieścić także w zakresie pojęcia ,zamek” (Pietrzak 2003, s. 22) ${ }^{16}$. Anna Marciniak-Kajzer wskazuje, że za synonim dworu (rycerskiego) uważany jest tzw. gródek stożkowaty, choć już wielokrotnie zwracano uwagę, jak duże jest to uproszczenie (Marciniak-Kajzer 2011, s. 11; 2013, s. 32-33) ${ }^{17}$. Jej zdaniem określenie „gród” ma zupełnie inne konotacje (por. wyżej), nie kojarzy się raczej z domem, nawet dużym, jednej rodziny. Uważa ona, że znacznie bardziej stosownym określeniem byłoby „dworzysko", nazwa ta jednak nie przyjęła się w terminologii archeologicznej (Marciniak-Kajzer 2011, s. 11; 2013, s. 32-33). Ostatecznie za archeologiczną pozostałość dworu rycerskiego A. Marciniak-Kajzer uznaje przede wszystkim tzw. gródki lub grodziska stożkowate ${ }^{18}$, cyplowe lub pierścieniowate, nie rezygnując ze względów stylistycznych z posiłkowania się terminem „dworzysko” (Marciniak-Kajzer 2011, s. 11; 2013, s. 32-33) ${ }^{19}$. Pozostałości w postaci tzw. grodzisk stożkowatych

${ }^{13}$ Ostatnio wydane opracowanie dworów rycerskich w Polsce - por. Marciniak-Kajzer 2016.

${ }^{14}$ Większość dworów murowanych w Polsce Centralnej lokowana była na kopcach lub wyspach, otoczona nawodnionymi fosami lub innymi obwodami obronnymi, które znacznie bardziej niż ognioodporna bryła budynków decydowały o ich obronności (Kajzer 2004, s. 126).

${ }^{15}$ Janusz Pietrzak jako „dwór obronny” określa założenie o czytelnej funkcji obronno-rezydencjonalnej lub rezydencjonalno-obronnej, dla którego sprawdzają się nie wszystkie (z punktu widzenia historii architektury, a więc w sensie przestrzennym, obronnym i budowlanym) desygnaty pojęcia „zamek” sensu stricto (Pietrzak 2003, s. 22).

${ }^{16}$ Por. też uwagi Stanisława Kołodziejskiego na temat pojęcia „dwór obronny” (Kołodziejski 1994, s. 11-12).

${ }^{17}$ Na przykład J. Rozpędowski uważał, że odpowiednikami tzw. gródków stożkowatych są obiekty (zamki) z wieżą mieszkalną - keep, na przykład Piekary i Siedlęcin (Rozpędowski 1978, s. 93).

${ }^{18}$ Określenia „gródek” i ,grodzisko”, jako przyjęte potocznie, używane są wymiennie (Marciniak-Kajzer 2011, s. 9).

19 Tzw. gródek stożkowaty, czy raczej grodzisko stożkowate, to stanowisko archeologiczne mające wyodrębnioną formę terenową, najczęściej w postaci kopca lub przestrzeni zamkniętej dookolnymi obronnymi wałami (Marciniak-Kajzer 2011, s. 9). Należy tutaj podkreślić odmienność formalną tego rodzaju obiektów od klasycznych grodzisk pierścieniowatych, co jest wynikiem nie tyle przemian formalnych, ile całkowicie innych historycznie mechanizmów rozwoju społeczeństwa polskiego między epoką państwa prawa książęcego a początkami (i następnie rozwojem oraz upadkiem) systemu feudalnego, w klasycznym rozumieniu tej formacji społecznej. Stąd też częste jeszcze wymienianie w jednym szeregu obu tych grup warowni traktować można jako informację o niezrozumieniu prawideł przemian historycznych badaczy uprawiających archeologię historyczną (Kajzer 1996, s. 126). 
można by określić też jako relikty grodźców ${ }^{20}$, czyli każdego zamku pełniącego funkcję obronnej siedziby feudała, charakteryzującego się niewielkimi rozmiarami i zredukowanym programem użytkowym, sprowadzającym się najczęściej do drewnianej lub murowanej wieży mieszkalno-obronnej w obrębie obwodu obronnego (Kołodziejski 1994, s. 12) ${ }^{21}$.

Kolejne postawione w naszym wywodzie pytanie powinno dotyczyć źródeł pisanych, a ściślej czy na podstawie przekazów pisanych można uznać niektóre obiekty za zamki, grody, czy też dwory, ewentualnie domniemywać o rodzaju lub formie takiego obiektu ${ }^{22}$. Z terminów zarejestrowanych w różnego rodzaju dokumentach określających grody i/lub zamki najbardziej popularne jest castrum. Jednak już Saba J. Dobrzański, studiujący dogłębnie problematykę castrum, stwierdził, że brak rodzimych, jednoznacznych odpowiedników nie tylko tego terminu, ale także pokrewnych (castellum, oppidum, civitas i urbs), które przekłada się jako gród lub miasto, a często niewłaściwie według niego jako zamek ${ }^{23}$ (Dobrzański 1978, s. 5-6). Castrum w znaczeniu kasztelanii występuje w dokumentach Konrada II Mazowieckiego z 1203 roku i papieża Innocentego III z 1216 roku (MPH, s. 422-424; Kodeks dyplomatyczny, nr 55). Warto podkreślić, że rzymskie terminy castellum/burgus i castrum oznaczały przede wszystkim obwód warowny. Castrum, castellum i oppidum miały więc wspólny element - obwód obronny. Wyraz castrum oznaczał zaś zawsze obóz wojskowy (Dobrzański 1978, s. 7, 10). Tak więc termin castrum mógł być użyty na określenie grodu ${ }^{24}$. $Z$ kolei nazwa burg, zapożyczona przez Rzymian w formie burgus od Germanów, pierwotnie oznaczała umocnienie w postaci obwodu na płaszczyźnie wzgórza (Dobrzański 1978, s. 10). Później jednak (jako Burg) określała różne układy funkcjonalno-przestrzenne - miasto, osiedle warowne i zamek (Dobrzański 1978, s. 11).

Zdaniem D. Nowakowskiego od końca XIII wieku występujące w przekazach castra można identyfikować także z obiektami typu motte. Stosowane w odniesieniu do nich różne terminy poświadczają jednocześnie sygnalizowaną już ich zmienność i wieloznaczność, na przykład Ryczeń koło Góry na Śląsku był wzmiankowany jako curia (1345 rok), castrum (1347 rok) i hus (1353 rok) (Nowakowski 2017, s. 85-86). Z kolei drewniany dwór w Stawie koło Błaszek

${ }^{20}$ Termin ten, który także zasadniczo nie przyjął się w literaturze przedmiotu, został zaproponowany przez Stanisława Kołodziejskiego (1994, s. 12).

${ }^{21}$ Janusz Bogdanowski jako przykłady grodźców podał obiekty w Siedlątkowie, Żywcu, Siedlęcinie, Janowiczkach i Melsztynie (Bogdanowski 2002, 49).

${ }^{22} \mathrm{Z}$ dość obszernej polskojęzycznej literatury na ten temat - por. np. Kołodziejski 1994, s. 11-13; Pietrzak 2003, s. 19-22; Kajzer 2004, s. 141-142; Marciniak-Kajzer 2011, s. 9-12; Jóźwiak, Trupinda 2012, s. 36, 96-98.

${ }^{23}$ Zdaniem Leszka Kajzera $\mathrm{z}$ wielu obiektów określanych w źródłach pisanych jako castrum, zdecydowana większość była jeszcze drewniano-ziemnymi grodami (Kajzer 2004, s. 25).

${ }^{24} \mathrm{~W}$ odniesieniu zwłaszcza do obszarów przygranicznych, na których zarówno wsie, jak i osiedla, bywały często obwarowywane, określenie castrum mogło, choć brzmi to paradoksalnie, dotyczyć nawet wsi (Dobrzański 1978, s. 13). 
w Polsce Centralnej był wymieniany w źródłach pisanych jako castrum (1422 rok), fortalicium (1432 i 1488 rok) i curia [...] in monte (1468 rok), a po przebudowie na murowany obiekt (po 1622 roku) nazywany był zamkiem (Kajzer 2004, s. 141-142).

Na ziemiach polskich główną, wojskowo-administracyjną część założenia urbanistycznego zwano posadką (Dobrzański 1978, s. 14) ${ }^{25}$. W adaptowanej terminologii łacińskiej nazywano ją: castrum lub castellum, zawsze municio, jeżeli chodziło o podkreślenie jej militarnego charakteru (Gall Anonim, III.1) ${ }^{26}$. Część gospodarczą - podgrodzie - początkowo nieumocnioną, w miarę czasu nazywano civitas, urbs, rzadko proastia, później suburbium. Często jednym z tych terminów określano cały układ przestrzenny, przy czym niewątpliwie dużą rolę odgrywała tu przewaga którejś z jego funkcji. W polskich źródłach pisanych pojawia się również arx w znaczeniu twierdzy i rezydencji książęcej w (przy) mieście (Dobrzański 1978, s. 14). Autor „Kroniki Wielkopolskiej” w XIII wieku część grodu santockiego, w którym przebywała drużyna wraz z rzemieślnikami i inną ludnością, nazywał po prostu castrum maius, natomiast gród, w którym zwykł urzędować książę (lub jego przedstawiciel) - castrum minus (Kronika, s. 150; Leciejewicz 1978, s. 53). Z kolei Jan Długosz w III i IV księdze swych „Roczników” konsekwentnie małe założenia militarne określał jako: municiones i fortalicja, większe - castra; pisząc o zameczku średniowiecznym w Szaflarach podaje, że pierwotnie było tu fortalicium ligneum (Dtugosz, s. 437-438; Dobrzański 1978, s. 13).

W średniowieczu używano wyrazu castrum zamiennie z castellum, a nawet civitas. Można jednak dokonać rozgraniczenia. Castrum, jeżeli nie odnosiło się do obszaru, oznacza zawsze duże, stale użytkowane miejsce, natomiast castellum - fortyfikacje (Ordericus 1969, IV. 1125: munitiones quas castella...nuncupant). Między pojęciami castrum a castellum zachodzi stosunek nadrzędności, tzn. że istnieją warowne miejsca będące desygnatami i nazwy castrum i nazwy castellum, ale nie ma takich warownych miejsc, które byłyby castrum nie będąc castellum. Określeniem warownej placówki militarnej był zaś termin municio oraz powstały w średniowieczu (XII wiek) i rozpowszechniony w XIV wieku fortalicium $^{27}$ (Dobrzański 1978, s. 16).

Od początku warownego budownictwa krzyżackiego w Prusach łacińskie słowa domus i castrum były zarezerwowane oraz zamiennie odnoszone do określania siedzib komtura i konwentu. Niemieckim odpowiednikiem domus było słowo hus. Termin hus jest identyfikowany z polskim ,zamek”, jednak

${ }^{25}$ Według Lecha Leciejewicza posad to podgrodowe osady rzemieślniczo-kupieckie (Leciejewicz 1978, s. 54).

26 Samodzielną część fortyfikacji miasta, przeznaczoną do ochrony przed atakami z zewnątrz i rozruchami wewnętrznymi, nazywano często po prostu castrum, przeważnie zaś arx (Dobrzański 1978, s. 13).

27 Termin fortalicium jako określenie niewielkich założeń obronno-rezydencjonalnych, przede wszystkim dworów na kopcach, bardzo często spotykany jest w źródłach z terenu Królestwa Polskiego (np. Kajzer 1987, tab. 1). 
z wyraźnym zaakcentowaniem funkcji mieszkalnej (Jóźwiak, Trupinda 2012, s. 96-97) ${ }^{28}$. Z kolei termin arx występuje w znaczeniu castrum - ufortyfikowanej placówki militarnej, którą nazywano Hauss (hus): wyraz arx... oznacza Hauss (Hartknoch 1679, s. 427; Dobrzański 1978, s. 15). W północnych Niemczech terminem tym określano twierdze i zamki z odcieniem znaczeniowym Schloss ${ }^{29}$. W kronice Mikołaja Jeroschina z XIV wieku na określenie zamku znajdujemy trzy słowa: burc, vestin i hus. Były one używane synonimicznie, przy czym hus mógł oznaczać właściwy zamek konwentualny ${ }^{30}$. Z kolei w „Starszej kronice wielkich mistrzów” (z XV wieku) zamki były ośrodkami władzy terytorialnej, co zostało wyrażone stosowanym terminem slosz (Jóźwiak, Trupinda 2012, s. 36, 38). Należy zaznaczyć, że pod koniec XIV i w 1. połowie XV wieku w krzyżackich źródłach zredagowanych w języku niemieckim pojawiały się różne formy terminu hus: hus, husz, huws (Jóźwiak, Trupinda 2012, s. 98). Z kolei wyrazem Wachhusz (dosłownie dom strażniczy) zwano często całe ufortyfikowane osiedle z wieżą obserwacyjną o charakterze refugialnym (LC, s. 13, 15; wg Dobrzański 1978, s. 15) (1) $^{31}$

Tak więc z przedstawionych powyżej rozważań wynika, że termin castrum, niezależnie od desygnatu, zachował swoje podstawowe znaczenie indoeuropejskiego pnia kastr (pojęcie cięcia, odcięcia) jako wydzielona powierzchnia zarówno w znaczeniu fizycznym (mur, wał, rów), jak i umownym (granica terenu) (Dobrzański 1978, s. 16).

Z kolei łacińskie określenie curia jest bardzo szerokie i wieloznaczne. Desygnatem tego terminu może być dwór, miejsce pobytu, siedziba władzy świeckiej i duchownej (rezydencja), a także budynek mieszkalny z podwórzem i zabudowaniami gospodarczymi (zespół domu feudała wraz z niezbędnym zapleczem zapewniającym jego właściwe funkcjonowanie). Natomiast fortalicium, także wieloznaczne określenie, jest tłumaczone najczęściej jako strażnica, mała forteca. Można przyjąć, że tak właśnie średniowieczni skrybowie nazywali dwory o mniej lub bardziej wyraźnie zaznaczonych walorach obronnych (Kajzer 2010, s. 43).

28 Wszystkie wymienione w dokumentach śląskie obiekty określane terminem Hus/Haus to fundacje książęce, względnie obiekty zbudowane na ich miejscu. W dawnym księstwie głogowskim termin Haus używany był wyłącznie w stosunku do okazałych siedzib rycerskich, zwykle zbudowanych na miejscu starych warowni książęcych (Nowakowski 2008, s. 246; 2017, s. 87).

${ }_{29}$ W niemieckim przekładzie „Legendy o św. Jadwidze” utożsamiono oba terminy: po rozgromieniu wojsk polskich w 1241 roku „Tatarzy nadciągnęli pod haus Legnicę, która w tym czasie nie była miastem [...] i wołali na tych, którzy znajdowali się w schloss" (Baumgarten 1504; wg Dobrzański 1978, s. 15).

${ }^{30}$ W „Wielkiej księdze urzędów” siedziba prokuratorów krzyżackich w Pniu pojawiła się w kontekście terminu huws (Das Grosse Ämterbuch, s. 463, 490), jednak trudno na tej podstawie sądzić, że chodzi tu o obiekt murowany, tak jak przypuszczają niektórzy badacze (Jóźwiak 2005, s. 98). Ponadto Pień nigdy nie był siedzibą krzyżackiego konwentu (Poliński 2013, s. 20-24). Jest to więc przykład pokazujący, że terminu hus nie należy łączyć wyłącznie z ośrodkiem komturskim.

31 Takie wieże obronno-refugialne i mieszkalne (donżon?) określano w Polsce jako słupy. Często przybierały one wygląd twierdz (Dobrzański 1978, s. 15). Na temat toponimów obronnych, w tym słupów szczegółowo - por. Kowalczyk 1992. 
Inne pojęcia (np. curia seu fortalicium, castrum seu fortalicium, fortalicium alias czwyerdze) pozwalają teoretycznie identyfikować fortalicję tak z dworem, jak zamkiem, czy twierdzą; często też spotykamy określenia curia et fortalicium, czy dostrzegające związek z wieżą turris (Kajzer 2010, s. 44). Określenia in monte, scopulus, mons, monticulum - informują o wznoszeniu fortalicji (obronnych dworów) na wzgórzach, pagórkach, wyniesieniach, sztucznie sypanych kopcach ziemnych, przez co można je identyfikować z późniejszymi, już polskimi założeniami typu „dwór na kopczu”, „dwór na kopcu”, „wieża z kopcem” lub „,siedlisko na kopcu". Natomiast określenie curia cum fossatum odnosić należy do polskich określeń typu „siedlisko z przykopem”, czy „dwór z przykopą”, informujących o ulokowaniu budynku na kopcu ziemnym, otoczonym rowem, najczęściej o charakterze nawodnionej fosy (Kajzer 2010, s. 44).

W odniesieniu do śląskich obiektów typu motte używano w przekazach pisanych najczęściej właśnie terminu curia lub $H_{o f}{ }^{32}$, rzadziej natomiast castrum/ Burg, castellum, fortalicium, Feste/Veste, Haus/Hus, propugnaculum/Bergfried, a w stosunku do najmłodszych (ze schyłku późnego średniowiecza i czasów nowożytnych) - Schloss, Gesesse, Sitz i Rittersitz. Określenia te były używane też zamiennie, niekiedy jako wyraźnie określone synonimy (Nowakowski 2017, s. 79). Materiał źródłowy ze Śląska świadczy o bardzo dużej różnorodności terminologii, a przykłady obiektów wielokrotnie wzmiankowanych w dokumentach pokazują, że różne nazwy często stosowano w odniesieniu do tego samego obiektu (por. wyżej). Z kolei konfrontacja źródeł pisanych z zachowanymi reliktami ujawniła, że niejednokrotnie tych samych terminów używano na określenie zarówno obiektów małych, jak i dużych. Zatem stosowana w dokumentach nomenklatura nie może być kryterium jednoznacznie rozstrzygającym o formie czy wielkości siedzib pańskich (Nowakowski 2017, s. 89) ${ }^{33}$.

Pojawiające się w literaturze przedmiotu próby łączenia występujących w średniowiecznych źródłach terminów, zwłaszcza łacińskich, z pewnymi układami przestrzennymi występującymi w architekturze militarnej są często chybione, bowiem zróżnicowane nazwy łacińskie są najczęściej synonimami (por. wyżej). Tak więc uogólnianie i automatyczne przenoszenie konkretnych pojęć na obiekty słabo rozpoznane archeologicznie może prowadzić na manowce (Nowakowski 2017, s. 13).

\footnotetext{
${ }^{32}$ Jakkolwiek określenia curia/Hof najczęściej thumaczy się jako dwór, to jednak - jak podają różne wydawnictwa słownikowe - termin ten miał w średniowieczu nawet kilkanaście znaczeń, na przykład na Śląsku używano go również na określenie parcel miejskich, dworów sołtysich, a nawet zagrody kmiecej (Nowakowski 2017, s. 79-80); por. też curia fortalicio (Nowakowski 2017, s. 82).

${ }^{33}$ Zaobserwowano jednak, że terminy castrum/Burg, Haus, Feste, Schloss stosowano raczej w odniesieniu do obiektów dużych, identyfikowanych zwykle z fundacjami książęcymi, zaś mniejsze, prywatne siedziby pańskie określano przeważnie jako propugnaculum i bergfried, w późniejszych przekazach - jako Gessese, Sitz i Rittersitz. Popularnego, ale i wieloznacznego terminu curia/Hof, często stosowanego w bardziej złożonych kombinacjach, używano zarówno w odniesieniu do obiektów okazałych, jak i mniejszych, identyfikowanych ze wszystkimi grupami fundatorów (Nowakowski 2017, s. 89).
} 
Niekiedy w przekazach pisanych można znaleźć jednak informację wskazującą na różnice w skali i jakości założeń obronnych; np. w akcie zastawienia przez Władysława Opolskiego położonych w ziemi dobrzyńskiej ...huser, Slös und festin... (slosse, howser und vesten) (1392 r.; Codex diplomaticus, nr 543, 544, 546; Pietrzak 2003, s. 20).

$\mathrm{Na}$ bardzo istotny przekaz źródłowy w odniesieniu do rozważanej problematyki zwrócił uwagę D. Nowakowski (2017, s. 249-250). Chodzi mianowicie o zbiór praw zwany „Zwierciadłem saskim” (Sachsenspiegel), który od końca XIII wieku obowiązywał także na Śląsku (versio Vratislaviensis). Dowiadujemy się z niego, że bez zgody landwójta można było budować: a) obiekty otoczone rowami tak głębokimi ,jak da radę wyrzucić ziemię człowiek szpadlem”; b) drewniane lub kamienne budynki o trzech kondygnacjach (przy czym jedna z nich musiała być zagłębiona w ziemię, a wejście znajdować się na poziomie pierwszej kondygnacji, nie wyżej niż na wysokości kolan); c) dwory umocnione płotem lub palisadą bez przedpiersi i tak wysoką, jak wysoko zdoła sięgnąć jeździec.

Już w okresie międzywojennym Hermann Uhtenwoldt podkreślał, że tzw. gródki stożkowate (czyli założenia typu motte) mieszczą się wprawdzie w definicji zamku, jednak jego zdaniem, w oczach współczesnych nie były to obiekty w pełni zasługujące na miano warowni i w żadnym wypadku nie należały do obiektów o znaczeniu strategicznym (Uhtenwoldt 1938, s. 146-147). Podobną opinię wyraził ostatnio D. Nowakowski, który sądzi ponadto, że pojawienie się obiektów typu motte na Śląsku nie miało większego związku z przełamywaniem regale grodowego, a zachowane ich pozostałości zdają się odpowiadać normom określonym w „Zwierciadle saskim” (Nowakowski 2017, s. 250).

Interpretacje informacji zawartych w wzmiankowanym źródle potwierdzają z jednej strony zróżnicowanie obiektów uznawanych przez nas za obronne lub obronno-rezydencjonalne i - moim zdaniem - pozwalają na zachowanie nazwy „zamek”, pojawiającej się w piśmiennictwie polskim od XV wieku (np. Rozpędowski 1978, s. 92; Guerquin 1984, s. 14), dla wielkich dzieł architektury militaris, w szczególności murowanych, pozostając przy odmiennych terminach („gród” czy „dwór”) w odniesieniu do założeń o znacznie mniejszej skali, w szczególności drewniano-ziemnych czy drewnianych.

Zróżnicowany obraz społeczeństwa doby feudalizmu (epoki późnego średniowiecza i początków czasów nowożytnych) spowodował, że powstawały wielkie siedziby mieszkalno-obronne (zamki) wznoszone przez władców, możnowładztwo świeckie i duchowne, wyznaczające centra administracji państwowej, rejony zagrożonych rubieży granicznych (a więc o czysto militarnym charakterze) i podporządkowane rozmieszczeniu wielkiej własności ziemskiej. Powstawały też znacznie liczniejsze, mniejsze założenia o charakterze mieszkalnym (grody?, dwory?) - redukcje wielkich dzieł architektury militaris, czyli zamków, których obronność była elementem wymaganym przez ówczesne konwencje, a pożądanym 
przez użytkowników (Kajzer 2004, s. 9-10, 146). Zróżnicowanie formalno-funkcjonalne interesujących nas średniowiecznych i nowożytnych obiektów, jak też w pewnym sensie specjalizacji badawczych zawiera się w stwierdzeniu L. Kajzera (1996, s. 113), że w ramach ,archeologii zespołów obronnych” porusza się między innymi problematykę: a) grodzisk, stanowiących relikty warowni powstałych z inicjatywy państwowej, od czasów pierwszych Piastów do rozbicia dzielnicowego; b) mniejszych warowni późnośredniowiecznych, nawiązujących do ogólnoeuropejskiego schematu siedziby typu motte; c) murowanych zamków funkcjonujących w Polsce od początku XIII wieku do czasów nowożytnych; d) innych małych, późnośredniowiecznych i nowożytnych założeń obronnych i obronno-rezydencjonalnych (w tym renesansowych dworów obronnych). Leszek Kajzer podkreślił przy tym, że chociaż różnice pomiędzy wyróżnionymi grupami założeń obronnych rysują się dość wyraźnie, to jednak w rzeczywistości granice między nimi są bardzo skutecznie zatarte, głównie na skutek wieloznaczności źródeł pisanych, nikłości ich trwałej substancji budowlanej, a także stanu zachowania.

Leszek Kajzer na terenach północnoeuropejskich, w tym na ziemiach polskich, w późnym średniowieczu, w ówczesnym krajobrazie - oprócz zamków - wyróżnił trzy typy założeń obronnych o umocnieniach drewniano-ziemnych - grodów (Kajzer 1988, s. 31-32):

a) ,stożkowate" - motte (tzw. model siedlątkowski) - drewniana wieża mieszkalna stojąca w centralnej partii górnej płaszczyzny ściętego stożka;

b) lokowane na dużym, płaskim i niewysokim (1-2 m) nasypie, na którym znajdował się dwór, a także budynki i zabudowania związane z obsługą zaplecza tego obiektu (wykonana w drewnie redukcja średniowiecznego zamku, różniąca się od niego budulcem, a niekiedy i skalą założenia);

c) „dwór za wałem”, w którym podstawową linię obrony tworzył dookolny wał ziemny ograniczający mały dziedziniec, na którym stał dom wieżowy (lub niski), a w przypadku większych rozmiarów majdanu również inne zabudowania.

Z kolei analizując szlacheckie siedziby warowne z czasów nowożytnych badacz ten także wyróżnił trzy zasadnicze typy (Kajzer 2004, s. 165-166):

a) motte (dwór na kopcu), najbliższy średniowiecznej tradycji, gdzie cała zabudowa towarzysząca, włącznie z kuchnią dworską, a także zespół zabudowań gospodarczych i folwarcznych, niekiedy uformowany wokół czworobocznego podwórca, pomieszczony był często w parkanie, ale poza kopcem;

b) redukcja, a właściwie dostosowanie do wymogów i możliwości szlachcica warowni typu palazzo in fortezza (najczęściej drewniana siedziba, ale niekiedy murowany dom pański); brzegami wyspy prowadzono drewniany parkan, najczęściej z otworami strzelniczymi, a niekiedy i z zadaszeniem, a na narożach stały „baszty”, czyli niskie, drewniane dzieła narożne, umożliwiające nie tylko ostrzał 
przedpola, ale i prowadzenie ognia równolegle do kurtyny (ostrzał krzyżowy); najważniejsze warownie tego typu powstały w 1 . połowie XVII wieku;

c) odmiana późnośredniowiecznego „dworu za wałem”, gdzie dom pański, a także całe szeroko rozumiane zaplecze rezydencji wraz z budynkami i zabudowaniami towarzyszącymi znajdowały się w obrębie rozległego, niskiego „kopca”, czy raczej niewiele wyniesionego plateau, otoczonego rowem - mokrą fosą, niekiedy wałem i (albo tylko) parkanem.

Na zakończenie niniejszych rozważań chciałbym zwrócić uwagę na jeszcze jedną kwestię. W Wojewódzkich Urzędach Ochrony Zabytków jest wyraźnie oddzielona dokumentacja dotycząca zamków murowanych oraz grodzisk. Odmawiając zasadności stosowania nazw „gród”, czy „dwór” (jednej z nich lub nawet obu) dla późnośredniowiecznych i nowożytnych obiektów warownych, a przynajmniej w stosunku do części z nich - w zamian używając także nazwy ,zamek”, przy jednoczesnym zachowaniu terminu „grodzisko" ${ }^{34}$ musielibyśmy niekiedy przyznać, że grodzisko kryje pozostałości zamku, a przecież na stanowisko będące pozostałością zamku jest odrębne, logiczne określenie - „zamczysko” (np. Guerquin 1984, s. 16). Myślę, że taka „rewolucja” nie jest potrzebna. Zamiast na siłę nazywać małe dzieła architektury militaris zamkami, lepiej byłoby zastanowić się nad adekwatnością stosowania terminów „gród” lub „dwór” w odniesieniu do założeń z późnego średniowiecza i młodszych ${ }^{35}$, biorąc pod uwagę ich genezę, funkcje oraz formę, przy czym za „grody” w pierwszej kolejności uznałbym obiekty stanowiące adaptacje i transformacje starszych założeń o genezie wczesnośredniowiecznej, których pozostałością są tzw. grody pierścieniowate ${ }^{36}$.

\footnotetext{
${ }^{34}$ Zdając sobie sprawę z braku precyzji historycznej tego terminu - por. uwagi L. Kajzera (1996, s. 113-114).

${ }^{35}$ Niekiedy z pewnością będzie można użyć określenia ,zamek (drewniany)”. Konstytucja roku 1616 mówi wprost o „[...] zgorzeniu zamku drzewianego [...] w Jezierzyskach na Ukrainie” (Pietrzak 2003, s. 20).

${ }^{36} \mathrm{Na}$ terytorium władztwa krzyżackiego byłyby to miejscowe obiekty zdobyte i adaptowane przez Krzyżaków - na przykład Stary Dzierzgoń (Poliński 2016a, s. 263-267), czy powstałe na miejscach dawnych grodów, czyli na grodziskach - na przykład krzyżacki Słup (Poliński 2016b) i rycerski Ryńsk (Kola 1991, s. 78-79, 88).
} 


\section{Bibliografia}

\section{Źródla}

$\begin{array}{ll}\text { Baumgarten 1504 } & \text { Baumgarten C., Alhy habet sich an dy grosse legende der } \\ \text { Codex diplomaticus } & \text { heiligen frawen sandt Hedwigis, Breslau 1504. } \\ - & \text { Codex diplomaticus Poloniae quo continentur privilegia } \\ & \text { regum Poloniae, magnorum ducum Lithuaniae, bullae } \\ & \text { pontificium (...), t. 2, wyd. L. Ryszczewski, A. Muczkowski, } \\ & \text { Varsoviae 1848-1853. } \\ \text { Das Grosse Ämterbuch }- & \text { Das Grosse Ämterbuch des Deutschen Ordens, } \\ & \text { red. W. Ziesemer, Danzig 1921. } \\ - & \text { Joannis Długosz senioris canonici cracoviensis Liber } \\ \text { Dtugosz } & \text { beneficiorum diocesis cracoviensis nunc primum, e co- } \\ & \text { dice autographo editus, t. 3, [w:] Opera omnia, t. 9, wyd. } \\ & \text { A. Przeździecki, Kraków 1864. } \\ - & \text { Galli Anonymi cronicae et gesta ducum sive principum } \\ & \text { Polonorum, Monumenta Poloniae Historica, Series Nova, } \\ & \text { wyd. K. Maleczyński, t. 2, Kraków 1952. } \\ - & \text { Hartknoch J. Ch., Selectae dissertationis historicae de variis } \\ \text { Gall Anonim } & \text { rebus Prussicis. Opera et studio Christophori Hartknoch, } \\ & 1679 . \\ \text { Hartknoch 1679 } & \text { Kodeks dyplomatyczny Ślaska. Zbiór dokumentów i listów } \\ & \text { dotyczacych Ślaqska, t. 1, wyd. K. Maleczyński, Wrocław } \\ & \text { 1956. } \\ \text { Kodeks dyplomatyczny } & \text { Kronika Wielkopolska, wyd. B. Kürbis, Warszawa 1970. } \\ - & \text { Kronika Marcina Bielskiego, t. III (ksiega VI. wraz } \\ & \text { z kontynuacya), wyd. K. J. Turowski, Sanok 1856. } \\ - & \text { Die Leutschauer Chronik des Caspar Hain, wyd. F. Mally, } \\ & \text { Prag 1943. } \\ - & \text { Monumenta Poloniae historica, Pomniki dziejowe Polski, } \\ \text { Kronika } & \text { t. 5, Lwów 1888. } \\ \text { Kronika polska } & \end{array}$

\section{Literatura}

Bogdanowski J.

2002 Architektura obronna w krajobrazie Polski. Od Biskupina do Westerplatte, Warszawa-Kraków.

Bogdanowski J., Holcer Z., Kornecki M.

1994 Architektura obronna. Słownik terminologiczny architektury, Warszawa. 
Boguszewicz A.

1998 Przemiany w XIII-wiecznym śląskim budownictwie obronnym, [w:] Kultura średniowiecznego Ślaska i Czech. ,, Rewolucja “XIII wieku, red. K. Wachowski, Wrocław, s. 97-111.

Dobrzański S. J.

1978 Castrum. Problematyka badawcza, [w:] Poczatki zamków w Polsce, red. M. Niemczyk, Prace Naukowe Instytut Historii Architektury, Sztuk i Techniki Politechniki Wrocławskiej, nr 12, Studia i Materiały, nr 5, Wrocław,

Durdík T. s. 5-21.

1978 Nástin vývoje českých hradù 12.-13. stoleti, Archaeologia historica, t. 3, s. $41-52$.

Gazda D.

2013 Między grodem a zamkiem - wieloczłonowe obiekty warowne prusko-krzyżackie na poludnie od Zalewu Wiślanego, [w:] Grodziska Warmii i Mazur 1. Stan wiedzy i perspektywy badawcze. Archaeologica Hereditas 2, red. Z. Kobyliński, Warszawa-Zielona Góra, s. 125-134.

Guerquin B.

1984 Zamki w Polsce, Warszawa.

Jóźwiak S., Trupinda J.

2012 Krzyżackie zamki komturskie w Prusach. Topografia i układ przestrzenny na podstawie średniowiecznych źródet pisanych, Torun.

Jóźwiak W.

2005 Prokuratorstwo krzyżackie w Pieniu w ziemi chetmińskiej (1414-1422).

Powstanie-funkcjonowanie-likwidacja, Zapiski Historyczne, t. 70, z. 2-3, s. $95-105$.

Kajzer L.

1980 Studia nad świeckim budownictwem obronnym województwa łęczyckiego w XIII-XVII wieku, Acta Universitatis Lodziensis, Folia Archaeologica 1, Łódź.

1987 Czy tzw. gródki stożkowate byly fundacjami „średniego rycerstwa”?, [w:] Średniowieczne siedziby rycerskie $w$ ziemi chetmińskiej na tle podobnych obiektów na ziemiach polskich, red. A. Kola, Toruń, s. 105-126.

1988 Archeologiczny rodowód dworu. Przemiany siedzib obronno-rezydencjonalnych Polski Centralnej w późnym średniowieczu i czasach nowożytnych, Łódź.

1993 Grodziska średniowieczne i nowożytne, Prace i Materiały Muzeum Archeologicznego i Etnograficznego w Łodzi, Seria Archeologiczna, nr 36 (1989-1990), s. 33-43.

1996 Wstęp do archeologii historycznej w Polsce, Łódź.

2004 Zamki i dwory obronne w Polsce Centralnej, Warszawa.

2010 Dwory w Polsce od średniowiecza do współczesności, Warszawa.

Kajzer L., Kołodziejski S., Salm J.

2003 Leksykon zamków w Polsce, Warszawa. 
Kola A.

1991 Grody ziemi chetmińskiej w późnym średniowieczu, Toruń.

Kołodziejski S.

1994 Średniowieczne rezydencje obronne możnowładztwa na terenie województwa krakowskiego, Kraków.

Kowalczyk E.

1992 „Nazwy obronne” Stup, Samborza i Zawada a zagadnienie obrony stałej ziem polskich $w$ średniowieczu, Warszawa.

Leciejewicz L.

1978 Gród i podgrodzie u Słowian zachodnich-problemy funkcji i rozwiązán przestrzennych, [w:] Początki zamków w Polsce, red. M. Niemczyk, Prace Naukowe Instytut Historii Architektury, Sztuk i Techniki Politechniki Wrocławskiej, nr 12, Studia i Materiały, nr 5, Wrocław, s. 51-57.

Marciniak-Kajzer A.

2011 Średniowieczny dwór rycerski w Polsce. Wizerunek archeologiczny, Łódź.

2013 Czego relikty skrywają średniowieczne, ,grodziska”. Refleksje po badaniach nie tylko w województwie warmińsko-mazurskim, [w:] Grodziska Warmii i Mazur 1. Stan wiedzy i perspektywy badawcze, Archaeologica Hereditas 2, red. Z. Kobyliński, Warszawa-Zielona Góra, s. 31-44.

2016 Archaeology on Medieval Knights'Manor Houses in Poland, Kraków-Lódź. Marschall P.

2007 The Motte in Great Britain: a summary, [w:] Motte - Turmhügelburg - Hausberg. Zum europäischen Forschungsstand eines mittelalterlichen Burgentypus, Beiträge zur Mittelalterarchäologie in Österreich, t. 23, s. 21-27.

Nowakowski D.

2008 Siedziby ksiązęce i rycerskie księstwa głogowskiego w średniowieczu, Wrocław.

2017 Śląskie obiekty typu motte. Studium archeologiczno-historyczne, Wrocław.

Ordericus V.

1969 Historia Ecclesiastica, Oxford.

Pietrzak J.

2003 Zamki i dwory obronne $w$ dobrach państwowych prowincji wielkopolskiej. Studium z dziejów państwowych siedzib obronnych na przełomie średniowiecza i nowożytności, Łódź.

Poliński D.

2005 Gród czy zamek? Z badań nad najwcześniejszymi krzyżackimi obiektami obronnymi w ziemi chetmińskiej, Archaeologia Historica Polona, t. 15/1, s. 181-196.

2013 Pień. Siedziba krzyżackich prokuratorów w ziemi chetmińskiej, Toruń.

2016a Problematyka adaptacji i transformacji na przykładzie krzyzackich grodów z terenu Prus $i$ Inflant, Archaeologia Historica Polona, t. 24, s. 261-283. 
2016b Castrum Starkenberg w świetle najnowszych badań nad krzyżackimi obiektami obronnymi, [w:] Życie społeczno-kulturalne w państwie zakonu krzyżackiego (XIII-XVI w.), red. J. Gancewski, K. Lisowska, S. Skiendziul, J. E. Śliczyńska, Olsztyn, s. 7-24.

Rozpędowski J.

1978 Gród a zamek - problem genezy i typologii, [w:] Początki zamków w Polsce, red. M. Niemczyk, Prace Naukowe Instytut Historii Architektury, Sztuk i Techniki Politechniki Wrocławskiej, nr 12, Studia i Materiały, nr 5, Wrocław, s. 91-96.

Stownik terminologiczny

1976 Stownik terminologiczny sztuk pięknych, red. S. Kozakiewicz, Warszawa. Uhtenwoldt $\mathrm{H}$.

1938 Die Burgverfassung in der Vorgeschichte und Geschichte Schlesiens, Breslau.

\section{STRONGHOLD OR CASTLE? THE REFERENTS OF TERMS AND THE CONSEQUENCES OF THEIR APPLICATION IN HISTORICAL ARCHAEOLOGY AND HERITAGE PROTECTION}

Keywords: Middle Ages, Post-Medieval period, stronghold, castle, manor, names of fortified structures in written sources (castrum, curia, hus, Schloss, fortalicium and others), historical archaeology, heritage protection.

Summary

The scope of research issues concerning both strongholds and castles is very complex and extensive, as evidenced by the enormity of literature on this subject. During the research, attempts were made to define the terms 'stronghold' and 'castle', also in the context of the defensive structures transformations. Opinions in this matter were expressed by both archaeologists as well as by historians of art and architecture. However, quite diverse views and positions developed to date leave doubts. This problem concerns, in particular, archaeologists studying defensive structures from historical times, forced to take into account ex definitione results of studies of historians. Therefore, it is worth once again to consider some issues related to this subject, in particular the consequences of using these terms in historical archaeology and heritage protection.

It should be emphasised that these considerations will not lay claim to a comprehensive and detailed approach to the topic, being rather a voice in discussion, based on various examples of structures, including the area of the Teutonic Knights authority, especially those which allow us to look in a different way at the seemingly obvious issues.

Presentation of the subject is not possible without defining basic terms and determination of their referents. It is also necessary to take into account the nomenclature from written sources, mainly medieval and post-medieval ones, in connection with socio-economic and political determinants. With this knowledge, it is possible to verify some theories and hypotheses regarding the development of defensive architecture, in which the forms of settlement such as strongholds and castles are generally perceived. Despite the fact 
that linking the terms appearing in medieval sources, especially Latin ones, with some spatial arrangements appearing in military architecture are often misguided (differential Latin names are most often synonyms), sometimes information can be found in written records indicating differences in scale and quality of defensive structures.

In conclusion, after analysing both archaeological sources as well as written accounts, taking into account previous studies of the issues in question, considering the diversity of medieval and post-medieval defensive or defensive-residential structures, the term 'castle', appearing in Polish literature from the $15^{\text {th }}$ century one should apply to great works of architecturae militaris, especially masonry ones, sticking with different terms ('stronghold' or 'manor') in relation to the structures of a much smaller scale, in particular the wooden-earthen or wooden ones. At the same time, as 'strongholds' in the first place I would consider structures which are adaptations and transformations of older complexes of early medieval origin, the remainder of which are so-called ring forts. 